\title{
CLEAN AND HEALTHY BEHAVIOR WITH OREM THEORY APPROACH TO IMPROVE KNOWLEDGE AND ATTITUDES ADOLESCENT ABOUT PREVENTION OF SCABIES IN THE ORPHANAGE
}

\author{
Ari Damayanti Wahyuningrum dan Misbahul Subhi \\ STIKES Widyagama Husada
}

\begin{abstract}
Scabies is a skin infestation by Sarcoptes scabiei. Several risk factors for scabies infestation is individual personal hygiene and environmental sanitation is not maintained, density, crowding, poverty, lack of knowledge, direct contact with the infested person and use of contaminated equipment. According to Orem theory of self care every individual has the ability to care for themselves so that they can maintain the health and welfare of yourself. The purpose of the study was to investigate knowledge and attitude of adolescent in Nurul Abyadh Orphanage Malang in healthy behavior and on handling scabies.

Desain use pre test post test non equivalent control group. The population adolescent Orphanage Nurul Abyadh as the treatment group was 38 respondents and adolescent Orphanage Sunan Ampel as the control group was 29 respondents, taken according to inclusion criteria. Research variables include of knowledge variable and attitude variable. Data were collected using structure questionnaire. Data were then analyzed using level of significance $\leq$ 0,05. Before and after treatment using analysis of the Wilcoxon and Mc Nemar, treatment and control groups using Mann Whitney and Chi Square.
\end{abstract}

Keywords: clean and healthy behavior, Orem theory approach, knowledge and attitudes, orphanage 


\section{ABSTRAK}

\section{PENDAHULUAN}

Scabies adalah infestasi kulit oleh Sarcoptes scabiei yang menimbulkan gatal (Brunner \& Suddarth, 2002). Penyakit ini ditemukan pada orang miskin dengan kondisi lingkungan dan hygiene di bawah standar, anak yang tinggal serumah dengan teman terinfeksi atau saling berganti pakaian sumber penularan infeksi. Tungau sering menular diantara orang yang tidur bersama, melalui pakaian, seprei, handuk dan benda lain yang digunakan secara bersama (Andersen et al, 2009). Tungau membuat terowongan di bawah lapisan kulit epidermis dan menyimpan telur dalam lubang. Beberapa hari menetas tungau muda (larva). Ciri khas scabies antara lain gatal hebat semakin memburuk pada malam hari, lubang tungau tampak garis bergelombang dengan panjang 2,5 cm. Lubang atau terowongan tungau dan gatal sering ditemukan di sela-sela jari tangan, pergelangan tangan, sikut, ketiak, sekitar puting payudara wanita, alat kelamin pria, sepanjang garis ikat pinggang dan bokong bagian bawah. Infeksi jarang mengenai wajah, kecuali pada anak dimana lesi muncul sebagai lepuhan berisi air (Chosidow, 2006). Hal tersebut jika tidak dilakukan penanganan dapat mengganggu aktifitas sehari-hari penderita scabies.

Epidemiologis scabies terjadi pada seluruh negara dan beberapa daerah seperti Kepulauan Carribean merupakan endemik (Ira, 2000). Dalam beberapa tahun terakhir, epidemik pada panti asuhan dan beberapa tempat padat penduduk. Scabies merupakan penyakit endemi masyarakat, disebabkan infestasi dan sensitasi Sarcoptes scabies Var Hominis. Penyakit scabies mengenai semua ras dan golongan di seluruh dunia, dijumpai pada anak dan orang dewasa muda, mengenai semua umur (Currie \& Carthy, 2010). Insiden scabies di negara berkembang menunjukan siklus fluktuasi interval antara akhir dari epidemi dan permulaan epidemi berikutnya $\pm 10-15$ tahun. Di beberapa negara berkembang, prevalensi scabies $\pm 6 \%-27 \%$ dari populasi umum (Eko, 2005). Di Indonesia tahun 2008 prevalensi scabies di beberapa pemukiman padat (panti asuhan, rumah susun) sebesar 5,60-12,95\% menduduki urutan ketiga dari 12 penyakit tersering sedangkan di Malang tahun 2010 
prevalensi scabies sebesar $18,3 \%$ (Adin, 2011).

Beberapa faktor resiko infestasi terhadap scabies adalah personal hygiene perseorangan dan sanitasi lingkungan tidak terjaga, kepadatan, kesesakan, kemiskinan, kurang pengetahuan, kontak langsung dengan orang terinfestasi, penggunaan peralatan terkontaminasi (Depkes RI, 2001). Hal tersebut ditemukan pada panti asuhan dengan penghuni padat, prevalensi scabies mencapai $78,7 \%$, dan prevalensi lebih tinggi terdapat pada kelompok higiene kurang baik $(72,7 \%)$ sedangkan pada kelompok higiene baik prevalensi scabies 2,2\%-3,8\%. Panti asuhan dikategorikan sebagai hunian kumuh karena tidak tersedia sarana layak di bidang sanitasi, data yang ada sekitar 211 juta orang terkena penyakit kulit tahun 2008. Sebanyak $90 \%$ dari penyakit kulit 50\% jarang mandi, $28 \%$ sering berganti pakaian dengan teman, $11 \%$ kurang kebersihan lingkungan. Hal tersebut memicu timbulnya berbagai macam penyakit kulit seperti panu, kadas, dan scabies (Andersen, 2009). Berdasarkan hasil study pendahuluan dilakukan peneliti angka prevalensi scabies sebesar $11,1 \%$ pada remaja di panti asuhan Nurul Abyadh Malang, mempunyai anak asuh 45 orang terdiri dari 24 perempuan dan 21 laki-laki. Usia 7-10 tahun sebanyak 7 anak, usia 11-16 tahun sebanyak 4 anak, usia 17-20 tahun sebanyak 34 anak. Padatnya tempat tinggal di panti asuhan Nurul Abyadh Malang di mana luas kamar tidur anak asuh perempuan ukuran $10 \times 12 \mathrm{~m}^{2}$ di tempati 24 anak sedangkan anak asuh laki-laki luas kamar tidur ukuran 10x10,5 $\mathrm{m}^{2}$ ditempati 21 anak dalam 1 tempat tidur ukuran $90 \mathrm{~cm} x$ $180 \mathrm{~cm}$ ditempati 2 orang anak dengan keadaan kamar lembab serta ventilasi kurang. Kebiasaan anak asuh kurang baik dalam melaksanakan personal hygiene saling tukar menukar handuk, alat mandi dan saling pinjam pakaian antar teman. Sebagian besar anak asuh di panti asuhan Nurul Abyadh terkategori usia remaja. Remaja merupakan masa transisi antara periode anak dan dewasa meliputi segi fisik, fisiologi, sosial, ekonomi. Dalam masa transisi tersebut rentan mencontoh perilaku teman kurang baik salah satu penyelewengan kenakalan remaja yaitu tingkah laku yang tidak sesuai dengan norma antara lain egois, tidak menjaga kebersihan (Fatimah, 2000). Sedangkan kelompok kontrol yaitu anak remaja panti asuhan Sunan Ampel di Malang yang mempunyai karakteristik hampir sama dengan kelompok perlakuan yaitu mempunyai jumlah total keseluruhan 40 anak asuh terdiri dari 23 perempuan dan 17 laki-laki. Usia 7-10 tahun sebanyak 11 anak, usia 11-16 tahun sebanyak 4 anak, usia 17-20 tahun sebanyak 25 anak. Padatnya tempat tinggal di panti asuhan Sunan Ampel Malang dengan luas kamar tidur anak asuh perempuan ukuran 10x12 $\mathrm{m}^{2}$ di tempati 23 anak sedangkan pada anak asuh laki-laki luas kamar tidur ukuran 10x10,5 $\mathrm{m}^{2}$ ditempati 17 anak dimana 1 tempat tidur ukuran $90 \mathrm{~cm} \mathrm{x}$ $180 \mathrm{~cm}$ di tempati 2 orang anak dengan keadaan kamar lembab serta ventilasi kurang. Kebiasaan anak asuh yang kurang baik dalam melaksanakan personal hygiene saling tukar menukar handuk, alat mandi, dan saling pinjam pakaian antar teman. Sebagian besar anak asuh di panti asuhan Sunan Ampel terkategori usia remaja, sebagian anak asuh pernah mengalami scabies dengan angka prevalensi sebesar $7,5 \%$. 
Perilaku hidup bersih dan sehat (PHBS) menurut Keputusan Menteri Kesehatan RI No 1529/Menkes/SK/X/2010 adalah sekumpulan perilaku yang dipraktikkan atas dasar kesadaran sebagai hasil pembelajaran yang menjadikan seseorang, keluarga atau masyarakat mampu menolong dirinya sendiri (mandiri) di bidang kesehatan dan berperan aktif dalam mewujudkan kesehatan masyarakat. Sehat dan sakit seseorang ditentukan oleh perilaku manusia sendiri dimana perubahan perilaku bukan hal mudah karena menyangkut pengetahuan dan sikap, berkaitan erat dengan kebiasaan masyarakat suatu daerah. Perubahan perilaku terkait dengan promosi kesehatan sebagai upaya untuk meningkatkan kemampuan masyarakat melalui pembelajaran agar mereka dapat menolong diri sendiri sesuai kondisi sosial budaya setempat. Sebagaimana tercantum dalam Keputusan Menteri Kesehatan No 1114 / Menkes / SK / VII / 2005 tentang pedoman pelaksanaan promosi kesehatan. Menurut Orem dalam teori self care setiap individu mempunyai kemampuan merawat diri sendiri sehingga individu dapat memenuhi kebutuhan hidup, memelihara kesehatan dan kesejahteraan diri sendiri. Teori selfcare deficit merupakan inti dari teori Orem, dibutuhkan orang dalam keadaan tidak mampu atau keterbatasan memberikan self-care efektif secara terus menerus. Teori Orem belum diaplikasikan pada kasus scabies sedangkan pada kasus diabetes millitus dan stroke sudah diaplikasikan (Noval, 2009). Berdasarkan fenomena di atas peneliti tertarik mengambil judul penelitian perilaku hidup bersih dan sehat (PHBS) dengan pendekatan teori
Orem dapat meningkatkan pengetahuan dan sikap remaja tentang pencegahan scabies di panti asuhan Nurul Abyadh Malang, diharapkan dapat dijadikan bahan referensi untuk meningkatkan pengetahuan dan sikap remaja sehingga derajat kesehatan anak asuh meningkat.

\section{METODE PENELITIAN}

Desain penelitian yang digunakan dalam penelitian ini adalah "Pre Tes-Post Tes Non Equivalent Control Group" yaitu sebelum perlakuan pada semua kelompok dilakukan pengukuran awal (pre tes) selanjutnya pada kelompok perlakuan dilakukan intervensi sesuai dengan protokol uji coba yang direncanakan sedangkan pada kelompok kontrol tidak dilakukan intervensi kemudian dilakukan pengukuran akhir (post tes) pada semua kelompok. Sampel pada kelompok perlakuan dan kelompok kontrol tidak dilakukan randomisasi.

Penelitian dilaksanakan di panti asuhan, untuk mengumpulkan data peneliti menggunakan angket berisi pertanyaan tertutup (Closed Ended Question) menggunakan skala Likert yang dibuat oleh peneliti dengan mengacu pada kepustakaan terdiri dari 10 pertanyaan untuk mengukur sikap di kategorikan $4=$ sangat setuju (SS), $3=$ setuju (S), 2=tidak setuju (TS), 1=Sangat tidak setuju (STS) kemudian dikategorikan dalam favorable dan unfavorable. Sedangkan mengukur pengetahuan terdiri dari 10 pertanyaan pilihan ganda dikategorikan berdasarkan prosentase skor kriteria pengetahuan : $76-100 \%$ pengetahuan baik, $50-75 \%$ pengetahuan cukup, $<55 \%$ pengetahuan kurang.

Dari hasil penyajian kuesioner dijelaskan dengan menggunakan tabel 
tabulasi data penyataan pengetahuan dan sikap responden pre tes dan post tes pada kelompok perlakuan dan kontrol.
HASIL PENELITIAN

PEMBAHASAN

Hasil Penelitian

Tabel 1. Distribusi responden berdasarkan umur

\begin{tabular}{cccccc}
\hline No & Umur Remaja & \multicolumn{2}{c}{$\begin{array}{l}\text { Kelompok } \\
\text { Perlakuan }\end{array}$} & \multicolumn{2}{c}{ Kelompok Kontrol } \\
\cline { 3 - 6 } & & $\mathrm{n}$ & $\%$ & $\mathrm{n}$ & $\%$ \\
\hline 1 & $16-17$ tahun & 21 & 55,2 & 15 & 51,8 \\
\hline 2 & $18-20$ tahun & 17 & 44,8 & 14 & 48,2 \\
\hline & Total & 38 & 100 & 29 & 100
\end{tabular}

Tabel 1. Menggambarkan sebagian Kelompok perlakuan sebanyak 21 remaja besar umur responden berada pada stage $(55,2 \%)$ sedangkan kelompok kontrol remaja menengah yaitu $16-17$ tahun. sebanyak 15 remaja $(51,8 \%)$.

Tabel 2. Distribusi responden berdasarkan jenis kelamin

No Jenis Kelamin Remaja Kelompok Perlakuan Kelompok Kontrol

\begin{tabular}{cccccc}
\cline { 3 - 6 } & & $\mathrm{n}$ & $\%$ & $\mathrm{n}$ & $\%$ \\
\hline 1 & Laki-laki & 17 & 44,8 & 11 & 38 \\
\hline 2 & Perempuan & 21 & 55,2 & 18 & 62 \\
\hline & Total & 38 & 100 & 29 & 100 \\
\hline
\end{tabular}

Tabel 2. Menggambarkan sebagian besar responden mempunyai jenis kelamin perempuan. Kelompok perlakuan jenis kelamin perempuan sebanyak 21 remaja $(55,2 \%)$ sedangkan kelompok kontrol sebanyak 18 remaja $(62 \%)$.

Tabel 3. Distribusi responden berdasarkan jenis pendidikan

\begin{tabular}{cccccc}
\hline \multirow{2}{*}{ No } & $\begin{array}{c}\text { Jenis } \\
\text { Pendidikan }\end{array}$ & \multicolumn{2}{c}{ Kelompok Perlakuan } & \multicolumn{2}{c}{ Kelompok Kontrol } \\
\cline { 3 - 6 } & & $\mathrm{n}$ & $\%$ & $\mathrm{n}$ & $\%$ \\
\hline 1 & SMA & 13 & 34,2 & 13 & 44,9 \\
\hline 2 & SMK & 22 & 57,9 & 10 & 34,4 \\
\hline 3 & MA & 3 & 7,9 & 6 & 20,7 \\
\hline & Total & 38 & 100 & 29 & 100
\end{tabular}

Tabel 3. Menggambarkan sebagian besar jenis pendidikan responden kelompok perlakuan adalah SMK (sekolah menengah kejuruan) sebanyak 22 remaja $(57,9 \%)$ sedangkan kelompok kontrol jenis pendidikan terbanyak SMA (sekolah menengah atas) sebanyak 13 remaja $(44,9 \%)$. 
Tabel 4. Distribusi responden berdasarkan pernah menderita scabies atau tidak

\begin{tabular}{|c|c|c|c|c|c|}
\hline \multirow{3}{*}{ No } & \multirow{3}{*}{ Pernah mengalami scabies atau tidak } & \multirow{2}{*}{\multicolumn{2}{|c|}{ Kel Perlakuan }} & \multirow{2}{*}{\multicolumn{2}{|c|}{$\begin{array}{c}\text { Kel } \\
\text { Kontrol }\end{array}$}} \\
\hline & & & & & \\
\hline & & $\mathrm{n}$ & $\%$ & $\mathrm{n}$ & $\%$ \\
\hline 1 & Sedang menderita scabies & 5 & 13,1 & 3 & 10,3 \\
\hline 2 & Pernah mengalami scabies 1 kali & 4 & 10,6 & 2 & 6,9 \\
\hline 3 & Pernah mengalami scabies $>$ dari 1 kali & 3 & 7,9 & 1 & 3,5 \\
\hline \multirow[t]{2}{*}{4} & Tidak pernah mengalami scabies & 26 & 68,4 & 23 & 79,3 \\
\hline & Total & 38 & 100 & 29 & 100 \\
\hline
\end{tabular}

Tabel 4. Menggambarkan responden kelompok perlakuan maupun kontrol rata-rata pernah mengalami penyaki scabies akan tetapi sebagian besar responden tidak pernah mengalami scabies. Kelompok perlakuan sedang menderita scabies 5 remaja $(13,1 \%)$ sedangkan kelompok kontrol remaja sedang menderita scabies 3 remaja $(10,3 \%)$.

Tabel 5. Distribusi responden berdasarkan ras

\begin{tabular}{cccccc}
\hline \multirow{2}{*}{ No } & \multirow{2}{*}{ Ras } & \multicolumn{2}{c}{ Kel Perlakuan } & \multicolumn{2}{c}{ Kel } \\
& & \multicolumn{3}{c}{ Kontrol } \\
\cline { 3 - 6 } & & $\mathrm{n}$ & $\%$ & $\mathrm{n}$ & $\%$ \\
\hline 1 & Jawa & 26 & 68,4 & 23 & 79,3 \\
\hline 2 & Madura & 12 & 31,6 & 6 & 20,7 \\
\hline & Total & 38 & 100 & 29 & 100 \\
\hline
\end{tabular}

Berdasarkan tabel 5. pada kelompok perlakuan mayoritas berasal dari ras Jawa
(68,4\%) pada kelompok kontrol mayoritas berasal dari ras Jawa $(79,3 \%)$.

Tabel 6. Uji homogenitas

\begin{tabular}{clcc}
\hline No & Karakteristik & $\mathrm{Z}$ & $\mathrm{p}$ \\
\hline 1 & Umur & 0,916 & 0,372 \\
\hline 2 & Jenis kelamin & 0,587 & 0,881 \\
\hline 3 & Jenis pendidikan & 1,151 & 0,141 \\
\hline 4 & $\begin{array}{l}\text { Pernah mengalami } \\
\text { scabies }\end{array}$ & 1,044 & 0,201 \\
\hline 5 & Ras & 0,788 & 0,565 \\
\hline
\end{tabular}

Tabel 6. Menggambarkan hasil uji tersebut menunjukkan nilai signifikansi dari kelima karakteristik diatas lebih besar dari alfa $(\alpha=0,05)$. Hal ini berarti tidak ada perbedaan yang signifikan pada data umur, jenis kelamin, jenis pendidikan, pernah menderita scabies atau tidak, ras. 
Tabel 7. Pengetahuan remaja sebelum dan sesudah diberikan materi perilaku hidup bersih dan sehat (PHBS) dengan pendekatan teori Orem tentang pencegahan scabies

\begin{tabular}{|c|c|c|c|c|c|c|c|c|c|}
\hline \multirow{3}{*}{$\begin{array}{l}\mathrm{N} \\
\mathrm{o}\end{array}$} & \multirow{3}{*}{ Tingkat Pengetahuan } & \multicolumn{4}{|c|}{ Kel Perlakuan } & \multicolumn{4}{|c|}{ Kel Kontrol } \\
\hline & & \multicolumn{2}{|c|}{ Pre } & \multicolumn{2}{|c|}{ Post } & \multicolumn{2}{|c|}{ Pre } & \multicolumn{2}{|c|}{ Post } \\
\hline & & $\mathrm{n}$ & $\%$ & $\mathrm{n}$ & $\%$ & $\mathrm{n}$ & $\%$ & $\mathrm{n}$ & $\%$ \\
\hline 1 & Baik & 0 & 0 & 12 & $\begin{array}{c}17, \\
9\end{array}$ & 0 & 0 & 0 & 0 \\
\hline 2 & Cukup & 22 & 32,8 & 26 & $\begin{array}{c}38, \\
8\end{array}$ & 18 & 26,9 & 23 & $\begin{array}{c}34 \\
3\end{array}$ \\
\hline \multirow[t]{5}{*}{3} & Kurang & 16 & 23,9 & 0 & 0 & 11 & 16,4 & 6 & 9,0 \\
\hline & Total & 38 & 56,7 & 38 & $\begin{array}{c}56, \\
7\end{array}$ & 29 & 43,3 & 29 & $\begin{array}{c}43 \\
3\end{array}$ \\
\hline & Wilcoxon Post & \multicolumn{4}{|c|}{$p=0,000$} & \multicolumn{4}{|c|}{$p=0,227$} \\
\hline & Mann Whitney Pre & & & & & 607 & & & \\
\hline & Mann Whitney Post & & & & $\mathrm{p}=$ & 000 & & & \\
\hline
\end{tabular}

Berdasarkan tabel 7. hasil analisis Wilcoxon pada kelompok perlakuan diperoleh nilai $\mathrm{p}=0,000<0,05$ artinya ada perbedaan pengetahuan yang signifikan saat pre tes dan post tes. Sedangkan pada kelompok kontrol diperoleh nilai $\mathrm{p}=$ $0,227>0,05$ artinya tidak ada perbedaan pengetahuan yang signifikan saat pre tes dan post tes. Hasil analisis Mann Whitney saat pre tes diperoleh nilai $\mathrm{p}=0,607>0,05$

Tabel 8. Sikap remaja sebelum dan sesudah diberikan materi perilaku hidup bersih dan sehat (PHBS) dengan pendekatan teori Orem tentang pencegahan scabies

\begin{tabular}{|c|c|c|c|c|c|c|c|c|c|}
\hline \multirow{3}{*}{$\begin{array}{l}\mathrm{N} \\
\mathrm{O}\end{array}$} & \multirow{3}{*}{ Sikap } & \multicolumn{4}{|c|}{$\begin{array}{l}\text { Kelompok } \\
\text { Perlakuan }\end{array}$} & \multicolumn{4}{|c|}{ Kelompok Kontrol } \\
\hline & & \multicolumn{2}{|c|}{ Pre } & \multicolumn{2}{|c|}{ Post } & \multicolumn{2}{|c|}{ Pre } & \multicolumn{2}{|c|}{ Post } \\
\hline & & $\mathrm{n}$ & $\%$ & $\mathrm{n}$ & $\%$ & $\mathrm{n}$ & $\%$ & $\mathrm{n}$ & $\%$ \\
\hline 1 & Favorable & $\begin{array}{l}2 \\
2\end{array}$ & 32,8 & 30 & 44,8 & 11 & 16,4 & 8 & $\begin{array}{c}11, \\
9\end{array}$ \\
\hline 2 & Unfavorable & $\begin{array}{l}1 \\
6\end{array}$ & 23,9 & 8 & 11,9 & 18 & 26,9 & 21 & $\begin{array}{c}31, \\
3\end{array}$ \\
\hline & Total & $\begin{array}{l}3 \\
8 \\
\end{array}$ & 56,7 & 38 & 56,7 & 29 & 43,3 & 29 & $\begin{array}{c}43, \\
3\end{array}$ \\
\hline & Mc Nemar & \multicolumn{4}{|c|}{$\mathrm{p}=0,057$} & \multicolumn{4}{|c|}{$\mathrm{p}=0,581$} \\
\hline & Chi Square Pre & \multicolumn{8}{|c|}{$p=0,105$} \\
\hline & Chi Square Post & \multicolumn{8}{|c|}{$p=0.000$} \\
\hline
\end{tabular}

Berdasarkan tabel 8. hasil analisis $M c$ Nemar pada kelompok perlakuan diperoleh nilai $\mathrm{p}>0,05$ artinya bahwa diperoleh nilai $\mathrm{P}>0,05$ artinya bahwa artinya tidak ada perbedaan pengetahuan yang signifikan antara kelompok perlakuan dan kontrol sebelum perlakuan. Hasil analisis Mann Whitney saat post tes diperoleh nilai $\mathrm{p}=0,000<$ 0,05 artinya ada perbedaan pengetahuan yang signifikan antara kelompok perlakuan dan kontrol sesudah perlakuan. tidak ada perbedaan sikap yang signifikan pada kelompok perlakuan dan kelompok kontrol. Hasil analisis Chi 
Square diperoleh nilai $\mathrm{p}=0,105>0,05$ artinya bahwa tidak ada perbedaan sikap yang signifikan pada kelompok perlakuan dan kontrol saat pre tes. Sedangkan saat post tes hasil analisis Chi Square diperoleh nilai $\mathrm{p}=0,000<0,05$ artinya bahwa ada perbedaan sikap yang signifikan pada kelompok perlakuan dan kontrol.

\section{Pembahasan}

\section{Karakteristik Responden}

Berdasarkan hasil penelitian sebagian besar remaja terkategori periode remaja menengah dengan rentang umur 16-17 tahun dimana rentang umur tersebut tidak terdapat perbedaan signifikan dengan periode remaja akhir, jenis kelamin perempuan lebih banyak dari pada jenis kelamin laki-laki dikarenakan dari jaman dahulu, sejak manusia masih tinggal di gua, laki-laki cenderung melakukan kegiatan berbahaya dan mengancam jiwa. Menurut Menahem (2009) dalam teori genetik menyatakan perempuan mempunyai usia harapan hidup lebih tinggi dari laki-laki karena kromosom $\mathrm{X}$ memiliki fungsi menjaga keseimbangan sel, mengandung euchromatin, satu jenis protein melakukan regenerasi sel. Dengan demikian wanita lebih tahan terhadap penyakit genetik daripada pria karena wanita memiliki salinan (copy) kromosom $\mathrm{X}$ yang akan meng-copy dirinya sendiri jika kromosom yang satu rusak. Sedangkan laki-laki yang terkena penyakit di kromosom $X$, tidak akan mampu memperbaiki kromosom yang rusak karena tidak ada contoh salinan kromosom asli.

Jenis pendidikan responden terbanyak kelompok kontrol SMA sedangkan kelompok perlakuan SMK dalam hal ini tidak terlalu berpengaruh terhadap peningkatan pengetahuan dan sikap karena terkategori satu level pada sekolah menengah keatas. Sebagian besar responden tidak pernah mengalami scabies akan tetapi dengan jumlah penyakit scabies sedikit dapat mempengaruhi kesehatan responden lain. Jumlah ras terbanyak baik pada kelompok perlakuan maupun kelompok kontrol yaitu ras Jawa.

Pengetahuan Remaja Sebelum dan Sesudah Pemberian Materi Perilaku Hidup Bersih dan Sehat (PHBS) dengan Pendekatan Teori Orem tentang Pencegahan Scabies

Berdasarkan tabel 7. pengetahuan responden kelompok perlakuan dan kontrol pre tes dan post tes sebagian besar berpengetahuan cukup. Kelompok perlakuan pre tes dan post tes terdapat peningkatan pengetahuan $6 \%$ dimana saat post tes tidak ada responden berpengetahuan kurang sedangkan kelompok kontrol post tes pengetahuan responden meningkat 7,4\% akan tetapi masih ada yang mempunyai pengetahuan kurang. Dengan fenomena ini jika tidak diberikan intervensi berupa pemberian materi perilaku hidup bersih dan sehat (PHBS) tentang pencegahan scabies, rentan terjadi penularan scabies pada lingkungan panti asuhan.

Pengetahuan didefinisikan sebagai pengakuan intelektual dengan fakta kebenaran atau prinsip ditambah dengan pengamatan, pengalaman dan laporan serta merupakan hasil dari tahu dan ini terjadi setelah orang melakukan penginderaan terhadap sesuatu (Notoadmodjo, 2003). Tingkat pengetahuan dipengaruhi oleh pembelajaran pada responden remaja panti asuhan yang pernah menderita scabies ataupun tidak pernah mengalami 
scabies melalui pemberian materi perilaku hidup bersih dan sehat (PHBS). Menurut Tarwoto \& Wartonah (2003) bahwa pemeliharaan kebersihan diri merupakan tindakan membantu klien atau masyarakat memelihara kebersihan dan kesehatan diri seseorang untuk kesejahteraan fisik dan psikis bermanfaat mencegah penyakit, meningkatkan kepercayaan diri dan menciptakan keindahan. Perubahan ranah kognitif didahului oleh persepsi seseorang terhadap apa yang dialami sehingga muncul persepsi berdasarkan informasi yang diperoleh.

Salah satu aplikasi teori Orem supportive educative system yaitu dengan memberikan materi penyuluhan kesehatan tentang perilaku hidup bersih dan sehat (PHBS) tentang pencegahan scabies dengan metode ceramah dan diskusi. Kelompok perlakuan terdiri dari 1 kelompok beranggotakan 9 remaja dan 2 kelompok beranggotakan 10 remaja sedangkan kelompok kontrol terdiri dari 1 kelompok beranggotakan 9 remaja dan 2 kelompok beranggotakan 10 remaja. Piaget dalam Potter \& Perry (2007) perkembangan kognitif remaja berada dalam tahap operasional formal mulai berkembang kemampuan berfikir prilaku abstrak, muncul pemikiran ilmiah awalnya pemikiran kaku tetapi pemikiran tersebut dapat beradaptasi dan fleksibel serta mereka dapat menyarankan beberapa solusi.

Sikap Remaja Sebelum dan Sesudah Pemberian Materi Perilaku Hidup Bersih dan Sehat (PHBS) dengan Pendekatan Teori Orem tentang Pencegahan Scabies

Berdasarkan hasil penelitian pada tabel 8. kelompok perlakuan pre tes dan post tes sebagian besar menunjukkan sikap favorable dan ada pertambahan jumlah responden mempunyai sikap favorable saat post tes sebesar $12 \%$ sedangkan kelompok kontrol sebagian besar menunjukkan unfavorable dan ada pertambahan jumlah responden mempunyai sikap unfavorable saat post tes sebesar $4,4 \%$. Hal ini menunjukan perbedaan kondisi antara kelompok perlakuan dan kontrol dimana kelompok perlakuan telah mendapat intervensi berupa pemberian materi perilaku hidup bersih dan sehat (PHBS) tentang pencegahan scabies sebelum pelaksanaan post tes sedangkan kelompok kontrol mendapat intervensi materi perilaku hidup bersih dan sehat (PHBS) tentang pencegahan scabies setelah pelaksanaan post tes.

Menurut Notoadmodjo (2003), sikap merupakan reaksi atau respon seseorang terhadap suatu stimulus atau objek. Tahapan sikap terdiri dari empat tingkatan yaitu menerima, merespon, menghargai dan bertanggung jawab. Faktor yang mempengaruhi sikap seseorang antara lain 1) pengalaman pribadi, apa yang dialami membentuk, mempengaruhi penghayatan terhadap stimulus; 2) pengaruh orang lain yang dianggap penting, kecenderungan mempunyai sikap searah dengan orang lain yang dianggap penting; 3) pengaruh budaya yang dianut dapat mempengaruhi pola pikir; 4) lingkungan tempat tinggal merupakan faktor paling mempengaruhi pembentukan sikap seseorang; 5) media massa merupakan sarana informasi berpengaruh dalam pembentukan opini dan kepercayaan seseorang; 6) Pengaruh faktor emosional merupakan pernyataan yang didasari emosi berfungsi sebagai penyaluran frustasi atau pengalihan pertahanan ego. 
Karakteristik Responden Berdasarkan Pengetahuan dan Sikap

1. Jenis Ras Berdasarkan Pengetahuan dan Sikap

Jenis ras Jawa maupun Madura kelompok kontrol dan perlakuan menunjukkan perubahan peningkatan ke arah lebih baik pada post tes dapat dimungkinkan responden mencari informasi melalui sekolah, internet, diskusi dengan teman. Mayoritas responden dari kelompok perlakuan dan kontrol adalah ras Jawa, jenis ras tidak berpengaruh terhadap peningkatan pengetahuan dan sikap karena responden telah lama tinggal di panti asuhan tersebut sehingga pengaruh budaya asal tidak begitu terbawa dalam lingkungan budaya yang baru. Lingkungan budaya yang baru di panti asuhan yang telah mewarnai kehidupan sehari-hari responden. Menurut azwar (2007) salah satu faktor yang mempengaruhi pembentukan sikap yaitu lingkungan tempat tinggal seseorang yang meletakkan dasar pengertian dan konsep moral individu dalam pembentukan sikap.

2. Jenis kelamin Berdasarkan Pengetahuan dan Sikap

Jenis kelamin laki-laki maupun perempuan pada kelompok kontrol dan perlakuan menunjukkan ada perubahan peningkatan ke arah lebih baik pada saat post tes. Mayoritas responden dari kelompok perlakuan dan kontrol mempunyai jenis kelamin perempuan dimana jenis kelamin tidak berpengaruh terhadap peningkatan pengetahuan dan sikap seseorang. Terjadi peningkatan ke arah yang lebih baik dikarenakan terjadi pengulangan pertanyaan yang sama pada saat pre tes dan post tes dimungkinkan responden mencari informasi melalui sekolah, internet, diskusi dengan teman.

\section{Umur Berdasarkan Pengetahuan dan} Sikap

Kelompok kontrol saat pre tes remaja menengah sebagaian besar mempunyai pengetahuan cukup dan sikap unfavorable sedangkan saat post tes mempunyai pengetahuan cukup dan sikap favorable. Saat pre tes dan post tes remaja akhir sebagian besar mempunyai pengetahuan cukup dan sikap unfavorable. Pada kelompok perlakuan saat pre tes sebagian besar remaja menengah mempunyai pengetahuan kurang dan sikap favorable sedangkan saat post tes mempunyai pengetahuan cukup dan sikap favorable. Pada remaja akhir saat pre tes dan post tes sebagian besar mempunyai pengetahuan cukup dan sikap favorable. Hal ini karena pada kelompok kontrol tidak diberikan pemberian materi terlebih dahulu sehingga ada beberapa responden yang mempunyai sikap unfavorable saat post tes. Sedangkan kelompok perlakuan terjadi perubahan pengetahuan saat post tes karena telah diberikan materi terlebih dahulu sebelum dilakukan post tes hal ini terjadi proses pembelajaran untuk mengembangkan atau meningkatkan kemampuan tertentu. Menurut Azwar (2007) salah satu faktor yang mempengaruhi pembentukan sikap yaitu media massa membawa pesan sugesti mengarahkan opini seseorang dan apabila cukup kuat akan memberi dasar efektif dalam menilai sesuatu. Selain itu kematangan umur juga mempengaruhi pengetahuan 
seseorang bahwa makin tua usia seseorang maka proses perkembangan mentalnya bertambah baik hal ini didukung oleh Abu Ahmadi (2001) daya ingat seseorang itu salah satunya dipengaruhi oleh umur. Dari uraian ini maka dapat kita simpulkan bahwa bertambahnya umur seseorang dapat berpengaruh pada pertambahan pengetahuan yang diperolehnya.

\section{Jenis Pendidikan Berdasarkan Pengetahuan dan Sikap}

Kelompok kontrol jenis pendidikan terbanyak pada SMA sedangkan pada kelompok perlakuan jenis pendidikan terbanyak pada SMK. Pada lampiran 9 kelompok kontrol saat pre tes dan post tes sebagian besar mempunyai pengetahuan cukup dan sikap unfavorable. Pada kelompok perlakuan saat pre tes dan post tes sebagian besar mempunyai pengetahuan cukup dan sikap favorable. Jenis pendidikan tidak terlalu mempengaruhi dalam peningkatan pengetahuan dan sikap seseorang akan tetapi lingkungan sekitar tempat seseorang berinteraksi, pengaruh orang lain yang dianggap penting, paparan media massa. Menurut Notoatmodjo (2003) pengetahuan seseorang dipengaruhi oleh beberapa faktor antara lain fasilitas seperti majalah, koran, buku, televisi sebagai sumber informasi yang dapat mempengrauhi pengetahuan seseorang. Sosial budaya setempat dan kebiasaan keluarga dapat mempengaruhi pengetahuan, persepsi dan sikap seseorang terhadap sesuatu. Hal ini didukung oleh Azwar (2007) faktor-faktor yang mempengaruhi sikap seseorang antara lain media massa membawa pesan berisi sugesti yang mengarahkan opini seseorang apabila cukup kuat akan memberi dasar efektif dalam menilai sesuatu, individu cenderung memiliki sikap searah dengan sikap orang lain yang dianggap penting, lingkungan lembaga pendidikan yang meletakkan dasar pengertian dan konsep moral individu dalam pembentukan sikap.

\section{Pernah Atau Tidak Mengalami} Scabies Berdasarkan Pengetahuan dan Sikap

Sebagian besar responden tidak mengalami scabies baik pada kelompok kontrol maupun perlakuan. Kelompok kontrol pre tes dan post tes sebagian besar responden tidak pernah mengalami scabies dengan pengetahuan cukup dan sikap unfavorable. Pada kelompok perlakuan pre tes dan post tes sebagian besar responden tidak pernah mengalami scabies dengan pengetahuan cukup dan sikap favorable. Hal ini terjadi perbedaan sikap antara kedua kelompok karena pada kelompok perlakuan telah diberikan materi perilaku hidup bersih dan sehat (PHBS) tentang pencegahan scabies sebelum pelaksanaan post tes sedangkan kelompok kontrol diberikan materi perilaku hidup bersih dan sehat (PHBS) tentang pencegahan scabies setelah pelaksanaan post tes sehingga mempengaruhi respon seseorang terhadap suatu stimulus.

\section{KESIMPULAN}

1. Pemberian perlakuan berupa penyampaian materi perilaku hidup bersih dan sehat (PHBS) tentang pencegahan scabies dengan pendekatan teori Orem dapat 
meningkatkan pengetahuan remaja dalam pencegahan scabies.

2. Pemberian perlakuan berupa penyampaian materi perilaku hidup bersih dan sehat (PHBS) tentang pencegahan scabies dengan pendekatan teori Orem dapat meningkatkan sikap remaja dalam pencegahan scabies.

\section{DAFTAR PUSTAKA}

Adin.(2011).Scabies Referat. http:// kuliah.blogspot.com/2011/12/scabi es-atau-scabies-referat.html.

Diakses 18 Januari 2012.

Ali, Mohammad. (2004). Psikologi Remaja Perkembangan Peserta Didik. Jakarta:PT Bumi Aksara.

Alligood \& Tomey. (2002). Nursing Teori and Their Work. Mosby Elsevier. Philadelphia.

Andersen, B., Haugen, H., Rasch, M., et al.(2009). Outbreak of Scabies in Norwegian Nursing Homes and Home Care Patients: Control and Prevention. Journal of Hospital Infection, Volume 45, Issue 2, Pages 160-164.

Azwar.(2001).Metode

Penelitian.Yogyakarta:Pustaka

Pelajar.

Brunner \& Suddarth.(2002).Buku Ajar Keperawatan Medical-Bedah Edisi 8 Vol 3.Jakarta:Penerbit Buku kedokteran EGC.

Chosidow, Oliver.(2006).Nursing England Journal of Scabies. Volume 354, page 1718-1727.

Currie, B \& Carthy, J.(2010).Nursing England Journal Clinical Therapeutic of Scabies. Vol 362:717725.
Depkes RI.(2001).Buku Saku Pelaksanaan Perilaku Hidup Bersih dan Sehat (PHBS) bagi Masyarakat di Wilayah Kecamatan.

Fatimah, Nurul.(2000).Kenakalan Remaja. http://www.penyebabdampak.net /tqa/ kenakalan-remaja.htm. Diakses 12 Februari 2012.

Kepmenkes RI No 829/Menkes/SK/VII/1999 tentang Persyaratan Kesehatan Perumahan.http://www.dinkes/pe rsyaratan-kesehatanperumahan.html. Diakses 12 September 2012.

Kepmenkes RI No 1114/Menkes/SK/VII/2005 tentang Pedoman Pelaksanaan PromosiKesehatan. http://www.ighealth.org/Pedoma n-Penyelengaraan-Promkes.html. Diakses 12 September 2012.

Kozier \& Erb's. (2006). Fundamentals of Nursing Concepts, Process and Practice Eight Edition.United States of America:Pearson Education.

Kusuma, Kelana. (2011). Metodologi Penelitian Keperawatan Panduan Melaksanakan dan Menerapkan Hasil Penelitian. Jakarta:Trans Info Media.

Mansjoer, Arif.(2000). Kapita Selekta Kedokteran Edisi III Jilid 2. Jakarta:Media Aesculapius FK UI.

Notoadmodjo.(2003).Pendidikan dan Perilaku Kesehatan.Jakarta:Rhineka Cipta.

Notoadmodjo.(2007).Promosi Kesehatan dan Ilmu Perilaku.Jakarta:Rineka Cipta.

Noval.(2009).Konsep dan Aplikasi Teori Model Keperawatan Dorothea E Orem. 
Website:(http://noval.blogspot.co m/2009/10/konsep-dan-aplikasimodel-keperawatan.html).

Diakses 3 Agustus 2012.

Potter \& Perry.(2007).Basic Nursing Seventh Edition.Canada:Elsivier Mosby.

Price, Sylvia.(2006).Patofisiologi Konsep Klinis Proses-Proses Penyakit Edisi 6 Vol 2.Jakarta:Penerbit Buku Kedokteran EGC.

Rosyid. (2010). Konsep Modul. Website: (http://www.rosyid.info/2010/06/ pengertian-fungsi-dan-tujuanpenulisan.html). Diakses 18 Januari 2012.

Smith, KE; Wall, E.et al. (1999). The Effect of Temperature and Humidity on The off Host Survival of Psoroptes Ovis and Psoroptes Cuniculi Vet Parasitol.83:265-275.

Tarwoto \& Wartonah. (2003). Kebutuhan Dasar Manusia dan Proses Keperawatan Edisi 1. Jakarta: Salemba Medika.

Wong.(2005).Essentials of Pediatric Nursing Seventh Edition.USA.Elsivier Mosby.

Yusuf, Syamsu. (2005). Psikologi Perkembangan Anak \& Remaja. Bandung:PT Remaja Rosdakarya. 